\title{
IRS2 Gene
}

National Cancer Institute

\section{Source}

National Cancer Institute. IRS2 Gene. NCI Thesaurus. Code C24523.

This gene is involved in signal transduction and is associated with Diabetes Mellitus. 